\title{
POLEPŠOVACIA VÝCHOVA NA ÚZEMÍ DNEŠNÉHO SLOVENSKA OD POČIATKU 20. STOROČIA DO DRUHEJ SVETOVEJ VOJNY*
}

\author{
REFORMATORY TRAINING IN THE TERRITORY OF \\ TODAY'S SLOVAKIA FROM THE BEGINNING OF THE \\ 20TH CENTURY TO THE SECOND WORLD WAR
}

\author{
Dávid Pandy ${ }^{1}$ \\ https://doi.org/10.33542/SIC2021-1-05
}

\begin{abstract}
ABSTRAKT
Predložený článok sa využivaním metód analýzy a komparácie venuje výskumu polepšovacej (ochrannej) výchovy na území dnešného Slovenska v rámci pôvodne uhorskej právnej úpravyz počiatku 20. storočia a neskoršej unifikovanej československej právnej úpravy. Článok tiež skúma košické reálie výkonu ústavnej polepšovacej výchovy v skúmanom obdobi so zameraním na transformáciu pôvodne uhorského ústavu na československú inštitúciu a približuje problémy s tým spojené.
\end{abstract}

\begin{abstract}
Using the methods of analysis and comparison, the presented article deals with research of reformatory training in the territory of today's Slovakia in the framework of the originally Hungarian legal regulation from the beginning of the 20th century and the later unified Czechoslovak laws. The article also examines the realities of institutional reformatory training carried out in Košice in the researched period with a focus on the transformation of the originally Hungarian institution into a Czechoslovak institute and presents the problems associated with it.
\end{abstract}

\section{I. ÚVOD}

Stúpajúca kriminalita mládeže v Uhorsku koncom 19. a začiatkom 20. storočia a vznik nových kriminologických smerov v zahraničí viedli k spochybňovaniu efektivity a aktuálnosti právnej úpravy ukladania sankcií delikventným det'om a mladistvým $\mathrm{v}$ zmysle platných hmotnoprávnych noriem uhorského trestného zákona V/1878 (d’alej len uhorský trestný zákon). ${ }^{2} \mathrm{~V}$ ich zmysle boli vek detský (do 12 rokov) a vek mladistvý (12-16 rokov) vnímané ako dôvod trestnost' vylučujúci alebo znižujúci. V rovine sankcií to znamenalo, že voči det'om mladším ako 12 rokov nebolo vedenie trestného konania a uloženie sankcie prípustné, pričom situáciu detských delikventov trestný zákon d’alej nijakým spôsobom neriešil. Pokial' ide o mladistvých, ak bol tento schopný rozoznat' protiprávnost' svojho konania, trestný zákon mu v zásade umožňoval uložit' sankcie rovnakého druhu ako dospelým, iba v miernejšej podobe.

\footnotetext{
Táto práca bola podporená Agentúrou na podporu výskumu a vývoja na základe Zmluvy č. APVV-19-0419.

JUDr., Univerzita Pavla Jozefa Šafárika v Košiciach, Právnická fakulta, Slovenská republika

University of Pavol Jozef Šafárik in Košice, Faculty of Law, Slovak Republic.

2 Bližšie pozri: PANDY, D.: Ideové východiská determinujúce postavenie mladistvých v uhorskom trestnom práve v druhej polovici 19. a začiatkom 20. storočia. In: VIII. česko-slovenské právněhistorické setkání doktorandů a postdoktorandů: sborník z konference. Brno: Masarykova Univerzita, 2020, s. 249-262.
} 
Napravit' neschopnost' uhorského hmotnoprávneho trestného kódexu dostatočne reflektovat' potrebu diferenciácie druhov sankcií vo vzt'ahu k det’om a mladistvým si za ciel' vytýčila tzv. prvá trestná novela (zák. čl. XXXVI/1908, d’alej len prvá trestná novela) a neskôr v procesnej rovine aj zák. čl. VII/1913 o súdoch mladistvých. Aj vd'aka týmto normám tak bola uhorská právna úprava starostlivosti o mládež vo všeobecnosti považovaná za rozsiahlejšiu a intenzívnejšie realizovanú v porovnaní s ostatnými čast’ami monarchie. ${ }^{3}$ Uvedené pramene práva upravujúce nové a zreformované typy sankcií pre mladistvých pritom v dôsledku recepcie práva predstavovali právny základ postavenia mladistvých na území Slovenska aj v období medzivojnovej Československej republiky. Mílnikom vývoja skúmanej problematiky do 2. svetovej vojny sa stal aj unifikujúci československý zákon č. 48/1931 Sb. o trestnom súdnictve nad mládežou. Ciel’om tohto článku je vykonat' analýzu tzv. polepšovacej výchovy ako jednej zo sankcií ukladanej mladistvým páchatel'om v zmysle vyššie naznačených uhorských právnych predpisov, ako aj neskoršej unifikovanej československej právnej úpravy. V tejto súvislosti sa autor s použitím metódy komparácie pokúsi overit' hypotézu, že unifikovaná právna úprava bola na kvalitatívne vyššej úrovni ako výsledky uhorskej normotvorby. Ciel'om článku je tiež priblížit' výkon polepšovacej výchovy v Komenského ústave v Košiciach a v tejto súvislosti overit' hypotézu, že preberanie štátnej moci v ňom po vzniku Československej republiky bolo spojené so značnými t’ažkost’ami.

\section{UHORSKÁ PRÁVNA ÚPRAVA}

Inštitút polepšovacej výchovy bol zavedený do právneho poriadku platného na území Slovenska už uhorským trestným zákonom, jeho normatívna úprava bola však značne úzka. Obmedzovala sa iba na to, že vo vzt'ahu k mladistvým (12-16), ktorí nedokázali rozoznat' protiprávnost' svojho konania trestný zákon pripúšt'al ich umiestnenie do polepšovacieho ústavu najviac však do dovŕšenia ich 20. roku života (§ 84, ods. 2), ako aj to, aby osoby mladšie ako 20 rokov v ňom výnimočne vykonali uložený trest odňatia slobody v rozsahu 6 mesiacov, ktorý by inak vykonali v samoväzbe (§ 42).

Bola to až vyššie naznačená prvá trestná novela, ktorá v principiálnej aj vo vlastnej normatívnej rovine podstatne transformovala charakter a využívanie skúmaného inštitútu. $\mathrm{V}$ prvom rade je potrebné poznamenat', že prvá trestná novela nanovo upravila predpoklady trestnej zodpovednosti mladistvých. V zmysle jej ustanovení došlo k navýšeniu hornej hranice veku mladistvosti z pôvodných 16 na 18 rokov, dolná hranica pritom ostala zachovaná na dvanástich rokoch. Predpokladom trestnej zodpovednosti sa tiež stáva "rozumová a mravná vyspelost mladistvého potrebná kjeho trestnej zodpovednosti."

Ako sme naznačili v úvode, prvá trestná novela tiež zaviedla nový diapazón sankcií adresovaných skúmanej vekovej kategórii páchatel'ov (12-18). ${ }^{4}$ Možnost' uloženia tohoktorého druhu sankcie sa pritom odvíjala od danosti alebo absencie uvádzanej rozumovej a mravnej vyspelosti mladistvého potrebnej k jeho trestnej zodpovednosti.

Ak táto absentovala, prvá trestná novela umožňovala mladistvému uložit': a) domáci dozor, b) domáce alebo školské trestanie alebo c) polepšovaciu výchovu v prípade "ak je $v$ jeho doterajšom prostredí vystavený mravnej skaze alebo sa vydal cestou úpadku". V prípade ak mladistvý bol nositel'om uvádzanej rozumovej a mravnej vyspelosti, trestná novela pripúšt’ala uloženie: a) súdneho pokarhania, b) prepustenia na skúšku, c) polepšovacej výchovy a napokon d) trestu odňatia slobody. Polepšovacia výchova ako sankcia ukladaná súdom teda prichádzala

FICO, M.: L'udský vek ako okolnost' vylučujúca trestnú zodpovednost' v procese unifikácie československéhotrestného trestného práva. In: Historia et theoria iuris, roč. 9, 2017, č. 1-2, s. 48.

4 Pre úplnost' dodávame, že systém sankcií dotváral aj zák. čl. VII/1913, komplexná analýza všetkých opatrení však presahuje účel tohto článku, preto sa jej bližšie nevenujeme. 
do úvahy vo vzt'ahu ku všetkým mladistvým, bez ohl'adu na úroveň ich rozumovej a mravnej vyspelosti.

Výkonu polepšovacej výchovy sa však mohli podriadit’aj osoby mladšie ako 18 rokov, ktoré sa nedopustili trestného činu, ale v ich prostredí boli vystavení mravnej skaze alebo sa vydali cestou úpadku a to na žiadost' otca vykonávajúceho otcovskú moc, poručníka či prípadne iného úradu, inštitúcie, spolku, či osoby so súhlasom otca alebo poručníka.

Polepšovaciu výchovu je možné v kontexte skúmaných ustanovení vnímat' ako "prednostné opatrenie" a to vo vzt'ahu k evidentnej subsidiarite trestu odňatia slobody, ktorý bolo možné mladistvému (disponujúcemu potrebnou rozumovou a mravnou vyspelost'ou) uložit' len "ak je potrebné prísnejšie opatrenie...". ${ }^{5} \mathrm{~V}$ tejto súvislosti pre úplnost' dodávame, že trestná novela rozlišovala aj dodatočnú polepšovaciu výchovu, ktorá sa mala vykonat' po výkone trestu odňatia slobody ak "od nej bolo možné očakávat' podstatné mravné pretvorenie". ${ }^{6}$

V komparácii s uhorským trestným zákonom teda došlo jednak k rozšíreniu okruhu subjektov, ktorým mohla byt' táto sankcia uložená a taktiež $\mathrm{k}$ zmene jej charakteru $\mathrm{z}$ pôvodne výnimočného, doplňujúceho na prioritne ukladané opatrenie. V zmysle prvej trestnej novely sa pritom "pri výbere opatrenia berú do úvahy: osobitosti mladistvého, stupeň rozumovej a mravnej vyspelosti, životné pomery a všetky ostatné okolnosti. Nim zodpovedajúc súd spomedzi opatreni vymedzených $v$ bodoch $1-4 \$ 17$ zvolí v medziach zákona to, ktoré sa javí najviac želatelným z pohl'adu zabezpečenia budúceho správania a mravného rozvoja mladistvého." $\mathrm{V}$ uvádzanom ustanovení sa odzrkadl'uje ideové pozadie prvej trestnej novely ovplyvnené pozitivistickými kriminologickými smermi, ktoré sa spočíva $\mathrm{v}$ tom, že pre súd boli pri výbere optimálneho opatrenia primárne rozhodujúce osobné pomery mladistvého a už nie charakter (závažnost') spáchaného skutku.

Účelom polepšovacej výchovy nemalo byt' trestanie a represia, ale toto opatrenie predstavovalo nástroj na výchovu páchatel'a k práci a na jeho pretvorenie. ${ }^{7}$ Podl'a Bencsika predstavovala "polepšovacia výchova najdôležitejši nástroj pre výchovu a správny rozvoj mravnej a rozumovej vyspelosti mladistvých." ${ }^{8}$ Lörincz uvádza, že nešlo o trest, ale "preventívny zásah spôsobilý na nápravu životnej cesty mladistvého", pričom "úlohou tohto zásahu bolo jednak mladistvého vymanit'z doterajšieho škodlivého prostredia, ako aj korigovat' dovtedajšiu chybnú výchovu". ${ }^{9}$

Vyplýva to zo samotných zákonných ustanovení v zmysle ktorých "Súd nariadi polepšovaciu výchovu, ak je mladistvý vo svojom doterajšom prostredí vystavený nebezpečenstvu skazy, započal jeho úpadok, alebo v záujme rozumového a mravného rozvoja sa ochranná výchova ukazuje potrebnou z iného dôvodu." 10

Angyal uvádza, že ochrannú výchovu pritom bolo možné uložit' takým mladistvým páchatel'om, pri ktorých v záujme ich budúceho správania sa a mravného rozvoja je možné očakávat' úspech len pri dlhšiu dobu trvajúcej neustálej ústavnej starostlivosti. ${ }^{11} \mathrm{~V}$ zmysle litery zákona pritom "Polepšovaciu výchovu súd nariadi na neurčitú dobu, nesmie však trvat' po prekročeni 21 . roku života mladistvého. ${ }^{12}$ Dížku ochrannej výchovy teda trestná novela súdu ani neumožňovala stanovit', a to vychádzajúc z presvedčenia zákonodarcu o tom, že ju stanovit'

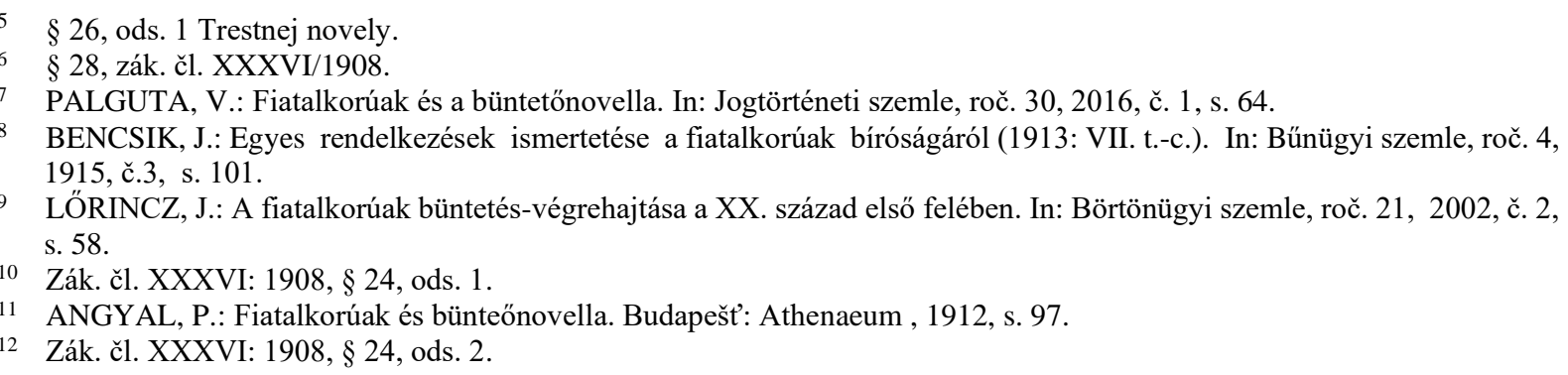


presne ani nemožno. Podl'a Edvi Illésa ciel' ochrannej výchovy a teda "pretvorenie charakteru, posilnenie ušlachtilých sklonov, zabrzdenie prízemných vášní, spevnenie schopnosti odolávat' citovým podnetom" je možné dosiahnut' u jednotlivých mladistvých v rozličnom časovom horizonte a preto jej trvanie vopred ohraničit' nemožno. ${ }^{13}$ Trestná novela však priamo vymedzovala objektívnu lehotu trvania polepšovacej výchovy a to najdlhšie do dovíšenia 21. roku veku. Systematickým výkladom pritom môžeme odvodit' aj minimálnu (subjektívnu) lehotu pre jej trvanie a to z ustanovení o skúšobnom prepustení z polepšovacej výchovy (vid' nižšie) v dížke jedného roka. Dížka trvania ochrannej výchovy teda v zásade závisela od veku páchatel'a v čase začiatku jej výkonu, nemohla však trvat' menej ako jeden rok. To odôvodňovala jej výchovná podstata, ktorá v kratšom trvaní nemala zmysel. Toto opatrenie teda $\mathrm{z}$ uvedeného dôvodu nebolo indikované pri páchatel'och starších ako 20 rokov. Niektorí autori poukazujú na prípady, kedy z dôvodu pobytu v cudzine nebolo možné na mladistvých ochrannú výchovu vykonat' a po ich návrate ostávalo do dovŕšenia 21. roku ich veku menej ako rok. Navrhovali preto, aby súdy páchatel’om vo veku 16-17 rokov ukladali ochrannú výchovu skôr výnimočne - jednak z vyššie naznačeného dôvodu, ako aj z obavy o jej efektívnost' v tejto vekovej kategórii. ${ }^{14}$

Trestná novela umožňovala, aby sa polepšovacia výchova vykonávala okrem štátnych polepšovní aj v iných štátnych zariadeniach slúžiacich na obdobný účel, najmä v detských azyloch (gyermekmenhely), alebo aj $\mathrm{v}$ iných zariadeniach vhodných na tento ciel' a to predovšetkým z kapacitných dôvodov. ${ }^{15} \mathrm{Na}$ jej výkon bolo možné využit' aj zariadenia spolkov či súkromných osôb. Tieto súkromné zariadenia boli podriadené ich zriad'ovatel'ovi, ale odborný dohl'ad nad nimi vykonával minister spravodlivosti. ${ }^{16}$ Výber zariadenia, do ktorého bude mladistvý umiestnený pritom neuskutočňoval súd, ale opät' minister spravodlivosti. Smerodajným mal byt' princíp, že "skazenejši odsúdení vyžadujúci prísnejši prístup vykonávali ochrannú výchovu v polepšovacích zariadeniach, miernejši pristup vyžadujúci trestanci zas $v$ detských azyloch a súvisiacich doplňujúcich zariadeniach." ${ }^{17}$

\section{Výkon polepšovacej výchovy podl’a uhorskej právnej úpravy}

Spôsob realizácie a podrobné pravidlá výkonu polepšovacej výchovy ustanovovalo nariadenie ministra spravodlivosti 27.200/1909 I.M. Z uvádzanej právnej úpravy vyvodzujeme nasledovné fázy ústavnej polepšovacej výchovy: 1. prijatie, 2. pozorovanie, 3 . výchova a 4. prepustenie.

Prvá fáza polepšovacej výchovy, ktorá začínala po dodaní mladistvého do ústavu bola tvorená úvodným pohovorom, založením dokumentácie o chovancovi a vstupným zdravotným vyšetrením. Úvodný pohovor realizoval s chovancom riaditel' ústavu alebo jeho zástupca. Dôverný rozhovor sa zameriaval na chovancovu minulost' a rodinné pomery, viedol k oboznámeniu chovanca s pravidlami ústavu a jeho obsahom bolo tiež upozornenie chovanca na skutočnost', že dížka jeho v pobytu v ústave závisí od jeho vlastného správania: "... nech mu jasne a l'ahko zrozumitel’ne vysvetli, že ak preukáže vytrvalú usilovnost' a bezvýhradné správanie, presne dodrži pravidlá ústavu, bude ho možné podmienečne prepustit'skôr, kým v opačnom prípade ho bude možné zadržiavat'v ústave do dov'ŕšnia 21. roku veku."18 Chovanec

13 EDVI ILLÉS, K.: Büntetőnovella zsebkönyve. 4. vydanie. Budapest: Révai testvérek irod. intézet b.t. kiadása, 1910, s. 163.

14 ANGYAL, P.: Fiatalkorúak és bünteőnovella. Budapešt': Athenaeum , 1912, s. 99.

15 Dôvodová správa Ministerstva spravodlivosti k Zák. čl. XXXVI:1908, Corupus Iuris Hungarici, 1908 évi t örvénycikkek. Budapest: Franklin- Társulat, 1909, s. 864.

16 LŐRINCZ, J.: A fiatalkorúak büntetés-végrehajtása a XX. század első felében. In: Börtönügyi szemle, roč. 21, 2002, č. 2 , s. 62.

17 EDVI ILLÉS, K.: Büntetőnovella zsebkönyve. 4.vydanie. Budapest: Révai testvérek irod.intézet b.t.kiadása, 1910 , s. 167.

$18 \S 33$ nar. 27.200/1909 I.M. 
mal následne absolvovat' vstupnú lekársku prehliadku za účelom zistenia resp. vylúčenia nákazlivých chorôb alebo tehotenstva. $\mathrm{Na}$ základe obsahu spisu, osobného pohovoru a lekárskeho vyšetrenia dochádzalo $\mathrm{k}$ vystaveniu príslušnej dokumentácie o chovancovi vrátane vyhotovenia fotografie. Po podrobení sa hygiene obdŕžal chovanec ústavnú rovnošatu, pričom jeho nepoužitel'né šatstvo bolo zničené, použitel'né šatstvo po dezinfekcii uskladnené alebo zaslané rodinným príslušníkom a cennosti uložené do úschovy.

Pri prechode do fázy pozorovania dochádzalo k vytvoreniu tzv. skúšobnej rodiny zloženej z najviac dvadsiatich novoprijatých chovancov. Ciel'om tejto fázy bolo zistit' povahu a mravné nedostatky chovanca a určit' pre neho smer vlastnej polepšovacej výchovy. Fáza pozorovania teda trvala do dosiahnutia ciel'a podl'a predchádzajúcej vety, najviac však 6 mesiacov. Počas pozorovania dochádzal chovanec $\mathrm{z}$ personálu do styku $\mathrm{s}$ tzv. vedúcim skúšobnej rodiny, riaditel'om ústavu a duchovným. Rozhodujúcu úlohu pritom podl'a nášho názoru zohrával samotný riaditel' ústavu, ktorého úlohou bolo " zistit' spôsob myslenia, zvyky, chut'k nejakému povolaniu, zabezpečit jeho oboznámenie sa s ústavnými dielňami, aby dostal chut'k niektorej činnosti pestovanej $v$ ústave."19 Už počas fázy pozorovania boli chovanci podrobení vzdelávaniu a výkonu domácich alebo iných prác.

Po fáze pozorovania nasledovala fáza vlastnej polepšovacej výchovy, ktorá bola v ústave organizovaná $\mathrm{v}$ tzv. výchovných rodinách. S rozsahom maximálne 30 osôb združovala výchovná rodina chovancov vykonávajúcich rovnaký druh práce, podobného veku a obdobného dovtedajšieho spôsobu života. Pravidlá ústavu však mohli ustanovit' aj d'alšie spôsoby triedenia chovancov najmä podl'a ich správania s možnost'ou "prestupu" z horšej skupiny s prísnejším režimom do lepšej skupiny s miernejším režimom alebo naopak, motivujúc tak chovancov k náprave. Fáza samotnej polepšovacej výchovy teda začínala vtedy, ked' sa zistili tie vlastnosti chovanca, ktoré ho umožnili preradit' zo skúšobnej rodiny v pozorovacej fáze do tej-ktorej výchovnej rodiny, započajúc tak vlastnú polepšovaciu výchovu. $\mathrm{Na}$ čele každej rodiny stál "vedúci rodiny", ktorý mal trávit' čas s chovancami po celý deň. "Úloha vedúceho rodiny je v rodine taká istá, ako úloha otca v rodine. On vedie vnútorný život rodiny podl'a domového poriadku ústavu". ${ }^{20}$ Vo výchove mu pomáhali "vedúci práce". Čas trávený $\mathrm{v}$ ústave $\mathrm{v}$ rámci výkonu polepšovacej výchovy delíme na: čas školský, čas pracovný a čas ostatný. Denný harmonogram určoval riaditel' ústavu tak, aby mladiství mali na spánok najmenej osem hodín, na stravu, hry a oddych najmenej štyri hodiny a zvyšný čas bol vyhradený výučbe a práci. Výučba sa zameriavala najmä na učivo ročníkov povinnej školskej dochádzky, okrem nej však boli chovanci vzdelávaní aj vo všeobecne prospešných praktických sférach ako zdravotníctvo, verejná správa či geografia. Okrem toho bolo možné vyučovat' aj teoretickú prípravu vo vzt’ahu $\mathrm{k}$ priemyselnej alebo pol’nohospodárskej práci vykonávanej $\mathrm{v}$ ústave. Výučbu vykonával vedúci rodiny, pričom vedomosti chovancov overoval na konci školského roka riaditel' ústavu skúšaním. Pokial' ide o pracovnú činnost', tá mala "okrem rozvoja charakteru a zušlachtovania mravnosti navyknút' chovancov na pravidelnú prácu a vytvorit' pevný základ pre ich budúcu obživu"21 pričom "chovancov (bolo) treba určenou prácou zamestnávat' tak, aby $v$ nej po prepustení pokračovali s možnost’ou zárobku". ${ }^{22}$ Pracovná činnost' teda nemala hospodársku, ale vzdelávaciu funkciu. Bola v zásade pol'nohospodárskeho alebo priemyselného charakteru, pričom dievčatá mali byt' vychovávané $\mathrm{v}$ prvom rade $\mathrm{k}$ domácim prácam. V snahe motivovat' chovancov $\mathrm{k}$ práci a podnecovat' ich $\mathrm{k}$ šetreniu patrila za pracovnú činnost' odmena. Počas dní pracovného pokoja výučba a práca neprebiehala a

\footnotetext{
$19 \S 39$ nar. 27.200/1909 I.M.

$20 \S 46$ nar. $27.200 / 1909$ I.M.

$21 \S 81$ ods. 2 nar. $27.200 / 1909$ I.M.

$22 \S 84$ ods. 1 nar. $27.200 / 1909$ I.M.
} 
chovanci sa mali zúčastňovat' na omši a zdokonal'ovat' sa v speve, hudbe či kresbe alebo mali vykonávat' iné užitočné činnosti. Tieto dni slúžili aj na prijímanie návštev a na písanie listov.

Poslednou etapou polepšovacej výchovy bolo prepustenie. Prepustenie vnímame ako samostatnú etapu z dôvodu, že okrem tzv. konečného prepustenia právna úprava rozlišovala aj prepustenie skúšobné, trvajúce po dlhší čas, nakol'ko bolo spojené s plynutím skúšobnej doby. Konečné prepustenie malo absolútny charakter a nastávalo ak chovanec dovíšil 21. rok veku (či už počas pobytu v ústave alebo počas plynutia skúšobnej doby) alebo ak po jeho skúšobnom prepustení uplynula skúšobná doba bez výhrad. Skúšobné prepustenie malo samozrejme relatívny charakter, ked’že správanie chovanca počas skúšobnej doby pred dovíšením 21. roku veku mohlo byt' podnetom pre jeho opätovné prijatie do ústavu. V zmysle prvej trestnej novely "Ak mladistvý, ktorý vykonáva polepšovaciu výchovu bol v zariadení umiestnený po dobu aspoň jedného roka a javí sa byt' úplne napraveným, v súčinnosti s dohliadajúcim orgánom ho môže minister spravodlivosti skúšobne prepustit’ na skúšobnú dobu 2 rokov." ${ }^{23}$ Procesný postup vedúci ku skúšobnému prepusteniu začínal predovšetkým návrhom riaditel'a ústavu adresovaným tzv. dohliadajúcemu orgánu ${ }^{24}$, ktorý následne návrh sprostredkoval ministrovi spravodlivosti. Žiadat' skúšobné prepustenie bol však oprávnený aj samotný mladistvý alebo jeho zákonný zástupca. Takúto písomnú žiadost' alebo zápisničné zachytenie ústnej žiadosti bolo potrebné predložit' dohliadajúcemu orgánu aj vtedy, ak riaditel' ústavu dôvody na skúšobné prepustenie nepovažoval za dané. Pred podaním svojho návrhu na skúšobné prepustenie riaditel' vypočul personál, ktorý prichádzal do styku s adeptom na prepustenie a vykonal potrebné opatrenia pre zabezpečenie jeho životných podmienok po prepustení. V zmysle ministerského nariadenia totiž: "Pokým nie je umiestnenie chovanca po skúšobnom prepustení zabezpečené, návrh na jeho prepustenie nie je možné podat." ${ }^{25}$ Princíp skúšobného prepustenia bol podl'a dôvodovej správy ten istý ako pri podmienečnom prepustení z výkonu trestu. Aj v tomto prípade bolo totiž žiadúce, aby mladistvý po získanej výchove bol po určitý čas pod dohl'adom. Trvanie skúšobnej doby vymedzovala prvá trestná novela pevne na dva roky, čo predstavovalo dvojnásobok trvania skúšobnej doby pri prepustení na skúšku. Dôvodom bola skutočnost', že súd v zásade ukladal polepšovaciu výchovu v porovnaní s prepustením na skúšku vo vážnejších prípadoch, mravne viac ohrozeným páchatel’om vyžadujúcim trvácejší dohl'ad. ${ }^{26}$ Angyal v tejto súvislosti uvádza, že pokial' ale ide o priebeh skúšobnej doby, ten sa výrazne nelíšil od skúšobnej doby pri prepustení na skúšku, ked’že aj v tomto prípade dohl'adom poverená osoba dohliadala na správanie mladistvého a v prípade porušenia pravidiel bezodkladne podala dohliadajúcemu orgánu hlásenie. ${ }^{27}$ Dohl’ad na mladistvým v skúšobnej dobe vykonával najmä patrón (probačný úradník). Dôsledkom oznámenia patróna o nevedení riadneho života mladistvým v skúšobnej dobe bolo podanie návrhu ministrovi spravodlivosti na nariadenie návratu mladistvého do ústavu. Orgánom rozhodujúcim o skúšobnom prepustení, ako aj o pokračovaní $\mathrm{v}$ polepšovacej výchove bol teda minister spravodlivosti ako predstavitel' exekutívy a nie súd. Edvi Illés v tejto súvislosti uvádza, že hoci na vyslovenie viny alebo uloženie obmedzenia osobnej slobody síce môžu byt' povolané iba nezávislé súdy, zverenie vyššie uvádzaných oprávnení týkajúcich sa skúšobného prepustenia exekutíve nie je možné považovat' za rozporné so základnými slobodami, pretože týmito právnymi aktami nedochádza

\footnotetext{
23 Zák. čl. XXXVI: 1908, § 25, ods. 1.

24 Zriadenie dohliadajúceho orgánu predvídal $\S 31$ prvej trestnej novely pri každom polepšovacom ústave a väznici určenej na prijatie mladistvých.

$25 \S 115$, ods. 5. nar. 27.200/1909 I.M.

26 Dôvodová správa Ministerstva spravodlivosti k Zák. čl. XXXVI/1908, Corupus Iuris Hungarici, 1908 évi törvénycikkek. Budapest: Franklin- Társulat, 1909, s. 865.

27 ANGYAL, P.: Fiatalkorúak és bünteőnovella. Budapešt': Athenaeum , 1912, s. 99.
} 
k d'alšiemu obmedzeniu osobnej slobody ale len "k poskytnutiu a prípadnému odňatiu určitej výhody v záujme spoločnosti a páchatel'a. "28

Uhorská právna úprava polepšovacej výchovy bola podl'a nášho názoru vypracovaná na vysokej kvalitatívnej úrovni. Polepšovacia výchova ako druh sankcie pritom tvorila logický prvok systému opatrení na nápravu mladistvých. Predpoklady jej využívania boli v právnej úprave logicky a zrozumitel'ne zadefinované a podmienky a spôsob jej výkonu bol podrobne prepracovaný.

Po vzniku Československej republiky došlo $\mathrm{k}$ recepcii právneho poriadku zanikajúcej monarchie zákonom č. 11/1918 Sb. o zriadení samostatného štátu československého, presnejšie jeho paragrafom 2, v zmysle ktorého: "Veškeré dosavadní zemské a řišské zákony a nařizení zůstávaji prozatím v platnosti." Jednou z najväčších výziev novoustanoveného štátu bolo počas celého medzivojnového obdobia odstránenie právneho dualizmu unifikáciou právneho poriadku. Na poli trestného práva ku komplexnej unifikácii $\mathrm{v}$ medzivojnovom období nedošlo ${ }^{29}$, unifikácia však bola úspešná čiastkovo, a to práve $\mathrm{v}$ oblasti trestného práva mladistvých.

\section{ZÁKON O TRESTNOM SÚDNICTVE NAD MLÁDEŽOU}

Zákon č. 48/1931 Sb. o trestnom súdnictve nad mládežou (d’alej len ZoTSM) bol úspešným výsledkom čiastkovej unifikácie medzivojnového československého trestného práva. Vládny návrh zákona vznikal za priamej a priebežnej účasti významných teoretikov trestnoprávnej vedy, z pražskej fakulty prof. Augusta Miřičku a z Brna prof. Jaroslava Kallaba. ${ }^{30}$ ZoTSM navýšil dolnú vekovú hranicu trestnej zodpovednosti na 14 rokov, v nadväznosti na čo rozlišoval medzi trestne nezodpovednými nedospelými (0-14) a mladistvými (14-18), pri ktorých bola predpokladom ich trestnej zodpovednosti aj schopnost' rozpoznat' protiprávnost' činu a ovládat' svoje konanie. Inštitút polepšovacej výchovy je v intenciách unifikovanej právnej úpravy označovaný ako ochranná výchova ${ }^{31}$ a spolu s ochranným dozorom predstavujú tzv. výchovné opatrenia ${ }^{32}$ vytvárajúc spolu s trestom odňatia slobody (tzv. zavretím) a peňažným trestom systém prostriedkov pre nápravu mladistvých.

ZoTSM rozlišoval tri stupne výchovných opatrení: ochranný dozor, ochrannú výchovu rodinnú a ochrannú výchovu ústavnú. "Ochranný dozor nariadi súd, ak uzná, že je síce nutné intenzivnejšie dohliadat' na riadnu výchovu mladistvého, avšak nie je treba vziat' ho z jeho doterajšieho prostredia, predovšetkým jeho vlastnej rodiny. Ak je nutné vymanit' neplnoletého $z$ nepriaznivého vplyvu jeho okolia, nariadi súd ochrannú výchovu. Tá bude vykonávaná pod dohl'adom súdu bud'v inej rodine alebo, najmä tam, kde bude treba prísnejšej disciplíny, vo výchovni." ${ }^{\prime 33}$ Československá právna úprava teda na rozdiel od uhorskej rozlišovala rodinnú a ústavnú ochrannú výchovu.

Ochrannú výchovu bolo možné v zmysle ZoTSM mladistvému uložit’ primárne:

28 EDVI ILLÉS, K.: Büntetőnovella zsebkönyve. 4. vydanie. Budapest: Révai testvérek irod.intézet b.t.kiadása, 1910 , s. 165.

29 K unifikácii trestného práva hmotného bližšie pozri: FICO, M.: Základy trestnej zodpovednosti v procese unifikácie trestného práva medzivojnovej Československej republiky. Košice: ŠafárikPress, 2020. 170 s. ISBN 978-80-8152-840-8.

30 FENYK, J. - CÍSAŘOVÁ, D.: Meziválečné trestní právo a věda trestního práva v Československu. In: Československé právo a právní věda v meziválečném období (1918-1938) a jejich místo ve Strědní Evropě, svazek 2. Praha: Karolinum, 2010, s. 830.

31 V zmysle § 69 ZoTSM sa: "polepšovacia ústavná výchova, ktorú nariadil, alebo ktorej prípustnost'vyslovil súd (poručenský úrad) podl'a zákona zo dňa 24. mája 1885 č. 89 a 90 ř.z., alebo podl’a zákonných článkov XXXVI/1908 a VII/1913 sa meni na ochrannú výchovu podla tohto zákona..."

32 Odôvodnenia vládneho návrhu zákona o trestnom súdnictve nad mládežou. In: MIŘIČKA, A. - SCHOLZ, O.: O trestním soudnictví nad mládeží. Praha: Československý kompas, 1932, s. 47.

33 Odôvodnenia vládneho návrhu zákona o trestnom súdnictve nad mládežou. In: MIŘIČKA, A. - SCHOLZ, O.: O trestním soudnictví nad mládeží. Praha: Československý kompas, 1932, s. 48. 
- poručenským súdom (úradom) v prípade oslobodenia mladistvého alebo ak súd získal vedomost' o potrebe jej uloženia mladistvému inak, ${ }^{34}$

- trestným súdom definitívne: v prípade vyslovenia viny súčasne s upustením od potrestania alebo spolu s uložením podmienečného trestu alebo nepodmienečného trestu; tiež trestným súdom dočasne: až do rozhodnutia poručenského súdu, ak je k tomu naliehavá potreba pri oslobodení mladistvého alebo ak sa trestný súd dozvie, že je takéto opatrenie potrebné a nie je možné sa ihned' dovolat' rozhodnutia poručenského súdu. ${ }^{35}$

O ukladaní ochrannej výchovy hovoríme aj v rovine sekundárnej a to:

- pri podmienečnom prepustení z trestu odňatia slobody (trest zavretia), kedy sa ochranná výchova alebo ochranný dozor ukladali obligatórne,

- pri riadnom prepustení z trestu zavretia, kedy sa ochranná výchova alebo ochranný dozor ukladali fakultatívne. $\mathrm{V}$ oboch prípadoch o tom rozhodovala tzv. dozorná rada príslušného ústavu na výkon trestu.

Ústavná ochranná výchova sa vykonávala vo verejných ústavoch a so súhlasom ministra sociálnej starostlivosti aj v súkromných ústavoch. Ústav, v ktorom sa vykonávala ochranná výchova sa označoval ako výchovňa ${ }^{36}$, ktorú je potrebné rozlišovat' od polepšovne ako ústavu na výkon trestu zavretia presahujúceho 6 mesiacov. Aj pri výchovniach sa zriad'ovala tzv. dozorná rada, "...ktorá sa skladala zo sudcu, ako jej predsedu a dvoch osôb činných vochrannej starostlivosti o mládež ako prísediacich. ${ }^{137}$ Významným okruhom pôsobnosti dozornej rady bolo rozhodovanie o prepustení chovancov. Ochranná výchova bola totiž rovnako ako v zmysle uhorskej právnej úpravy neurčitého trvania a "...potrvá tak dlho, pokial to jej účel, totiž polepšenie mladistvého vyžaduje". V nadväznosti na to platilo, že "Keďže odkázanie do ústavnej ochrannej výchovy nedeje sa nikdy na určitú dobu, ale na dobu pokial' to vyžaduje jej účel, nikdy však nie viac ako do dokonania dvadsiateho prvého roku, je nutné o prepustení vždy osobitne rozhodnut', a toto rozhodnutie prislúcha dozornej rade". ${ }^{38}$

Pokial' ide o spôsob výkonu ochrannej výchovy, ZoTSM obsahuje blanketovú normu, ktorá predvída prijatie samostatného zákona o výkone ochrannej výchovy. Do jeho prijatia mal byt' výkon ochrannej výchovy upravený vládnym nariadením podl'a zásad stanovených v ZoTSM. Vo vládnom nariadení z 11. decembra 1931 č. 195 Sb. z. a n., ktorým sa vykonáva ZoTSM, však vo vzt’ahu $\mathrm{k}$ výkonu ochrannej výchovy nachádzame iba $\mathrm{v}$ čast' IX. upravujúcu "Remeselnú výuku vo výchovniach a v polepšovniach". Domnievame sa pritom, že avizovaný zákon do rozpadu medzivojnovej republiky prijatý nebol. Naznačuje to aj Čič, ktorý uvádza ${ }^{39}$, že "V čase prijatia zákona č. 48/1931 Sb. zák. a nar. sa ešte počitalo s tým, že otázku ochranného dozoru a ochrannej výchovy upravi osobitne zákon o ochrannej výchove..." $\mathrm{Na}$ rozdiel od výkonu ochrannej výchovy bol výkon trestu zavretia podrobne upravený a to vo výnose ministerstva spravodlivosti č. 41209/31. Avšak v prípade, ak sa malo zavretie (trest odňatia slobody) vykonat' vo výchovni, $\mathrm{v}$ plnej miere platil domový poriadok ústavu. ${ }^{40}$ Vzhl'adom na vyššie uvedené sa preto domnievame, že konkrétne otázky výkonu ochrannej výchovy mohli byt' tiež ponechané úprave domového poriadku ústavu (výchovne).

\footnotetext{
34 KALlAB, J.: Stručný výklad zákona z 11. března 1931 č. 48 Sb . z. a n. O trestním soudnictví nad mládeží. Brno: Československý akademický spolok Právník, 1931, s. 15.

35 KALLAB, J.: Stručný výklad zákona z 11. března 1931 č. 48 Sb. z. a n. O trestním soudnictví nad mládeží. Brno: Československý akademický spolok Právník, 1931,. s. 24.

$36 \S 12$, ods. 2 ZoTSM.

$37 \S 62$, ods. 3 ZoTSM.

38 KALLAB, J.: Stručný výklad zákona z 11. března 1931 č. 48 Sb. z. a n. O trestním soudnictví nad mládeží. Brno: Československý akademický spolok Právník, 1931, s. 26.

39 ČIČ, M.: Ochranná výchova v československom trestnom práve. Bratislava: Obzor, 1971, s. 34.

40 Výnos ministerstva spravodlivosti zo dňa 11. septembra 1931 č. 41209/31 o výkone trestu zavretia, § 69.
} 
Vo výchovniach, ako je zrejmé z doterajšieho výkladu sa teda vykonávala predovšetkým ochranná výchova, za splnenia určitých podmienok však aj trest zavretia. "Tresty zavretia do šiestich mesiacov, po ktorých má nasledovat' ochranná výchova vo výchovni alebo ktoré sa majú vykonat' na chovancoch výchovne, majú byt' spravidla vykonávané vo výchovni, v ktorej sa vykonáva alebo má byt’ vykonaná ochranná výchova. Vo všetkých ostatných prípadoch je $k$ výkonu trestu zavretia vo výchovni potrebný súhlas ministra spravodlivosti. ${ }^{41} \mathrm{Nad}$ rámec uvedeného Výnos ministerstva spravodlivosti č. 37.775/1931 ustanovoval, že tresty uložené osobám mužského pohlavia súdmi v obvode Vrchného súdu v Košiciach sa budú vykonávat' vo väznici Krajského súdu v Košiciach, pričom toto oddelenie sa zároveň umiestňuje do Komenského ústavu v Košiciach a podriad’uje správe riaditel'stva tohto ústavu. ${ }^{42}$

\section{KOMENSKÉHO ÚSTAV V KOŠICIACH}

Dejiny Komenského ústavu v Košiciach sa začínajú písat' v roku 1896, kedy sa uhorské ministerstvo spravodlivosti uznieslo na zriadení ústavu pre výchovu opustenej mládeže v severnom Uhorsku. ${ }^{43}$ Prvý štátny polepšovací ústav bol pritom v Uhorsku zriadený už v roku 1884 v Aszóde (Peštianska župa), následne v roku 1886 v Kluži (Kolozsvár), v roku 1890 ústav pre dievčatá v Rákospalote (dnes mestská čast' Budapešti), v roku 1895 v Stoličnom Belehrade a napokon v Košiciach, kde bol ústav svojmu účelu odovzdaný v roku 1903. ${ }^{44}$ "Kapacita piatich ústavov predstavovala spolu 980 miest, pričom problémy s umiestňovaním chovancov sa začali prejavovat' až od 90-tych rokov. Čoraz viac narastajúce problémy s kapacitou navyšovalo to, že v dôsledku nedostatku vhodných inštitúcii polepšovacie ústavy prijímali okrem mladistvých odkázaných do ústavov súdmi, aj mladistvých vyžadujúcich po dlhší čas trvajúcu nútenú výchovu a to na žiadost' ich rodičov alebo poručnikov. ${ }^{45}$ Je tak možné domnievat' sa, že podnetom $\mathrm{k}$ zriadeniu košického ústavu bola najmä snaha riešit' črtajúci sa kapacitný nedostatok vtedajších polepšovacích ústavov v Uhorsku.

Vznik Československej republiky a preberanie moci československou vládou nad územím dnešného Slovenska neprebiehali jednoducho. Výskumom dostupných prameňov je možné dospiet' $\mathrm{k}$ záveru, že uvedené platilo rovnako aj vo vzt'ahu ku preberaniu správy československým štátom nad košickým ústavom. V tejto súvislosti pozorujeme dva okruhy problémov a to: personálne a materiálne.

Preberanie správy nad košickým ústavom nastalo predovšetkým personálnymi zmenami vo vedení ústavu a to 15. februára 1919, kedy na pozíciu hospodárskeho správcu nastúpil Edmund Borek a technickým správcom sa stal Kašpar Baluška-Mészáros. ${ }^{46}$ Dovtedy bolo v ústave ešte stále mad'arské vedenie zosobnené riaditel’om Fürstom. ${ }^{47}$ Právny základ transformácie ústavu do nových pomerov predstavovalo nariadenie vlády č. 136 z 22. februára 1919 o premene štátnej polepšovne v Košiciach, vydané Vavrom Šrobárom, ministrom Československej republiky s plnou mocou pre Slovensko. Jeho § 1 znel: "Štátnu polepšovňu v Košiciach "Állami javitó-nevelö intézet" premenúvam na Komenského ústav pre výchovu opustenej mládeže. Sídlo

41 Výnos ministerstva spravodlivosti zo dňa 11. septembra 1931 č. 41209/31 o výkone trestu zavretia, $\S 3$, ods. 1,2 .

42 Výnos ministerstva spravodlivosti zo dňa 1. septembra 1931 č. 37.775, č. 18. Věst, čl. II, bod 8.

43 STUNA, S.: Prehl'ad vývoja a pôsobenie ústavu. In: Komenského ústav v Košiciach 1919-1929. Košice: Štátna knihtlačiareň v Košiciach, 1929, s. 18.

44 LÖRINCZ, J.: A fiatalkorúak büntetés-végrehajtása a XX. század első felében. In:Börtönügyi szemle, roč.21, 2002, č.2, s. 58.

45 LŐRINCZ, J.: A fiatalkorúak büntetés-végrehajtása a XX. század első felében. In: Börtönügyi szemle, roč. 21, 2002, č. 2 , s. 58.

46 STUNA, S.: Prehl'ad vývoja a pôsobenie ústavu. In: Komenského ústav v Košiciach 1919-1929. Košice: Štátna knihtlačiareň v Košiciach, 1929, s. 18.

47 VÍTĚZ, J.: První počátky ústavu. In: Komenského ústav v Košiciach 1919-1929. Košice: Štátna knihtlačiareň v Košiciach, 1929, s. 12. 
ústavu je v Košiciach." Je možné zhodnotit', že toto nariadenie malo všeobecný a dočasný charakter a vo svojich jedenástich paragrafoch za účelom zachovania kontinuity ústavu vymedzovalo iba základné otázky jeho d’alšieho fungovania. Za osobitne významné považujeme $\mathrm{v}$ tomto kontexte ustanovenie $\S 9$ citovaného nariadenia, ktoré riešilo budúce personálne fungovanie ústavu. V jeho zmysle "úradníci a zamestnanci doterajšej štátnej polepšovne v Košiciach majú právo žiadat'o miesto $v$ ústave novo organizovanom, a to po zverejnenom konkurze, a pri rovnakej kvalifikácii majú prednost' pred inými žiadatel'mi." V praxi sa však personálna transformácia ústavu vyvíjala problematicky. Stuna, neskorší riaditel' ústavu uvádza ${ }^{48}$, že "vedenie ústavu s dovtedajšim mad'arským personálom bolo vel’mi t'ažké, javil sa vo valnej väčšine sklon ku komunizmu, tiež niektorí odopreli zložit’ sl’ub vernosti, takže muselo sa prikročit' dňa 15. mája 1919 k faktickému prevzatiu do čsl. správy". Dovtedy ústav ešte nebol úplne pod československou správou, skôr pod československým dozorom. "Doba štvormesačného dozoru čsl. priniesla pre čsl. živel trpkú skúsenost', lebo bol v ústave živelný odpor proti všetkému slovenskému, proti vládnej moci, demonštratívne sa nosili komunistické odznaky, čo všetko malo samozrejme zlý vplyv na mládež. ${ }^{\prime 49}$ Personálne problémy sa pritom prejavili najmä vo vzt'ahu $\mathrm{k}$ zabezpečovaniu pracovnej výučby v ústave. Vítěz uvádza: "Dña 15. mája 1919 mi bolo ako velitel'ovi pridelených niekol'ko vojakov, chystalo sa prevzatie ústavu do rúk čsl. štátu. Pre vedenie dielní bol za správcu ustanovený odborný učitel MeszarosBaluška. Tento vybral si niektorých zamestnancov z mad'arského režimu a zvyšok prepustil. Aby boli prepustení nahradení a aby v každej dielni bol aspoň jeden spol'ahlivý zamestnanec, požiadalo riaditel'stvo ústavu posádkové velitel'stvo, aby ústavu boli daní nejaki vojaciremeselníci. Vojenské velitel'stvo vyšlo žiadosti v ústrety a tak z týchto pridelených vojakovremeselníkov ešte niekol'ko slúži v ústave do dnešnej doby. ${ }^{\prime 50}$ Nedostatok odborného personálu bolo teda vedenie nútené riešit' dopĺn̆aním z radov československých vojakov. Môžeme pritom dodat, že $\mathrm{v}$ širšom zmysle transformácia ústavu po personálnej stránke sa netýkala len zamestnancov, ale aj samotných chovancov, ktorí mali byt' rozdelení na chovancov, ktorí zostanú v Československu a tých, ktorí poputujú do Mad’arska. V zmysle § 11 uvádzaného nariadenia: "S odoslaním chovancov príslušných do republiky Mad'arskej má sa začat' ihned". Chovanci na Slovensko príslušni budú prevzatí do Komenského ústavu pre výchovu opustenej mládeže." Do Mad'arska takto po prevzatí správy nad ústavom bolo odoslaných asi 60 chovancov a v košickom ústave zostali chovanci v počte asi $40 .{ }^{51}$

Popri nedostatku personálu čelilo nové vedenie Komenského ústavu aj nedostatku materiálneho vybavenia. Situáciu skomplikovala invázia vojst' Mad'arskej republiky rád do Košíc. Vítěz uvádza: "V poslednej chvíli sme ústav opustili. Pre nedostatok času a vagónov sa len vel'mi málo z ústavného majetku dalo zachránit." ${ }^{152}$ Po ústupe mad'arského vojska začala konsolidácia ústavu, realizovaná najmä pod vedením nového vedúceho ústavu, českého sudcu Dr. Augustina Bělohlávka, ktorý do svojej funkcie nastúpil od 1. septembra 1919. Na československé počiatky ústavu spomínal nasledovne: "Ked' som v r. 1919 preberal "Komenského ústav", nachádzal sa priamo v žalostnom stave. Bolo to krátko po invázii mad'arských bolševikov. Všetko čo bolo cennejšie a dalo sa l'ahko odniest' bolo mad'arskými

48 STUNA, S.: Prehl’ad vývoja a pôsobenie ústavu. In: Komenského ústav v Košiciach 1919-1929. Košice: Štátna knihtlačiareň v Košiciach, 1929, s. 18.

49 STUNA, S.: Komenského ústav v Košiciach. In: Jubilejný almanach mesta Košíc a Východ. Slovenska 1918-1928. Košice: Slovenská knihtlačiareň v Košiciach, 1928, s. 127.

50 VÍTĚZ, J.: První počátky ústavu. In: Komenského ústav v Košiciach 1919-1929. Košice: Štátna knihtlačiareň v Košiciach, 1929, s. 12.

51 STUNA, S.: Prehlad vývoja a pôsobenie ústavu. In: Komenského ústav v Košiciach 1919-1929. Košice: Štátna knihtlačiareň v Košiciach, 1929, s. 18.

52 VÍTĚZ, J.: První počátky ústavu. In: Komenského ústav v Košiciach 1919-1929. Košice: Štátna knihtlačiareň v Košiciach, 1929, s. 12. 
hordami odvlečené. Nebolo žiadnych zásob ani na potravinách ani na odevných súčastiach, dielne boli vyplienené, ba dokonca aj zariadenie pavilónov pre chovancov a kancelárii bolo z časti odvlečené." 53 Uvádza, že ústav trpel značnými materiálnymi problémami, vrátane nedostatku učebných pomôcok, nástrojov v dielňach, odevov pre chovancov, ako aj peňazí potrebných k nevyhnutným investíciám a platom zamestnancov.

Vzniknutú situáciu $\mathrm{v}$ otázke materiálnej bol ústav nútený riešit' úvermi od peňažných ústavov, nakol'ko československý štát ešte nemal vyriešenú otázku rozpočtu a vo vzt'ahu k dotáciám pre ústav bol zdržanlivý. Vo vzt’ahu k riešeniu personálnych kapacít Stuna uvádza, že: "Zo začiatku mal vedúci ústavu t'ažkú úlohu. Bolo treba ústav znovuvybudovat'. Bolo treba zaučit' zamestnanectvo do rôznej špeciálnej a zodpovednej služby, konali sa preto pre zamestnanectvo kurzy pestúnske, vychovávatel'ské, remeselnícke i telovýchovné. Po stránke pedagogickej boli zavedené rôzne metódy podl'a vzoru cudzozemských ústavov. "54 Vedenie ústavu čelilo v otázkach personálnych aj špecifickému problému spochybňovania platnosti menovacích dekrétov vydaných ministrom Šrobárom, ktorými boli zamestnanci menovaní do kategórií úradníckych a podúradníckych. $\mathrm{V}$ dôsledku toho boli títo zamestnanci ministerstvom prerad’ovaní z uvádzaných kategórií do kategórie "zriadeneckej". Bolehlávek v tejto súvislosti uvádza: "Z týchto nerozlúštených otázok vznikali vel'ké t’ažkosti a trenice medzi zamestnancami ústavu, ktoré sa zvyšovali ešte v dôsledku panujúcej núdze o byty a vôbec o vhodné ubytovanie pre zamestnancov. Jeden osočoval druhého bud' preto, že bol vo vyššej kategórii alebo $i z$ národnostných dôvodov a dokonca aj politická príslušnost' otravovala súžitie a poriadok $v$ ústave. ${ }^{\prime 55}$

Nariadenie vlády č. 136 z 22. februára 1919 o premene štátnej polepšovne v Košiciach bolo zrušené nariadením vlády č. 609 zo 14. novembra 1919, ktoré predstavovalo definitívnu právnu úpravu fungovania a postavenia košického ústavu. Jeho $\S 3$ nanovo zadefinoval okruh činností ústavu a ústav rozdelil na 2 samostatné oddelenia: odd. justičné a odd. "sociálnej pečlivosti". Na oddelení justičnom sa vykonávala polepšovacia výchova alebo trest odňatia slobody uložené trestnými súdmi a oddelenie sociálnej pečlivosti slúžilo $k$ výchove iných neplnoletých: $a)$ opustených, vo výchove zanedbaných, alebo mravne ohrozených, b) mladistvých osôb už trestaných alebo mravne porušených, pokial' bola potreba polepšovacej výchovy ohl'adom nich vyslovená sirotskou alebo policajnou vrchnost'ou alebo toho žiadajú ich rodičia, zákonný zástupca, spolok alebo iný podobný ústav, ktorý za súhlasu vlády Československej republiky stará sa o mládež. ${ }^{\prime 56}$ Počet chovancov na oddelení sociálnej pečlivosti však mohol dosahovat' maximálne $1 / 3$ z kapacity celého ústavu. Stuna uvádza, že "sú teda v K.Ú. vlastne dva ústavy, ale pod jednou administrativou. Obe oddelenia sú separovane ubytované, takže nebezpečie nepriaznivého vplyvu jedného na druhé je vylúčené." ochranná výchova ráz totožný, nakol'ko v obidvoch kategóriách niet vecného rozdielu. Tento rozdiel môže spočivat' len v tom, že títo mladíci, ktorí boli ústavu odovzdaní trestnými súdmi mládeže, prejavili svoju mravnú úchylnost'o niečo pozdejšie než druhí a takým spôsobom, že to zadalo hned' podnet $k$ súdnemu zakročeniu. Tiež u chovancov pečlivosti preventívnej stane

53 BĚLOHLÁVEK, A.: Komenského ústav před 10 lety. In: Komenského ústav v Košiciach 1919-1929. Košice: Štátna knihtlačiareň v Košiciach, 1929, s. 5.

54 STUNA, S.: Prehl'ad vývoja a pôsobenie ústavu. In: Komenského ústav v Košiciach 1919-1929. Košice: Štátna knihtlačiareň v Košiciach, 1929, s. 20.

55 BĚLOHLÁVEK, A.: Komenského ústav před 10 lety. In: Komenského ústav v Košiciach 1919-1929. Košice: Štátna knihtlačiareň v Košiciach, 1929, s. 8.

56 § 3 Nariadenia vlády č. 609 zo 14 . novembra 1919.

57 STUNA, S.: Komenského ústav v Košiciach. In: Jubilejný almanach mesta Košíc a Východ. Slovenska 1918-1928. Košice: Slovenská knihtlačiareň v Košiciach, 1928, s. 129. 
sa neraz takáto vec, ale rodičia včasným zakročením, najmä odčinením spôsobenej škody zásah trestného súdu predidu. ${ }^{58}$

V zmysle vyššie citovaného vládneho nariadenia stál na čele ústavu vrchný riaditel', ktorý podliehal priamo ministrovi spravodlivosti, ktorý ho menoval do funkcie po dohode $\mathrm{s}$ ministrom sociálnej starostlivosti. Predpokladom menovania do funkcie vrchného riaditel'a bolo splńnanie predpokladov pre výkon funkcie sudcu. Vrchnému riaditel'ovi podliehal všetok personál ústavu. V ústave sa vykonávala školská a "pracovná" výučba. $Z$ dostupných prameňov je zrejmé, že "Chovanci povinní školskou l'udovou (do 14 rokov) chodia do takejto školy $v$ ústave... Starši sú zamestnaní v remeslách a záhradníctve. Tí, ktorí nemajú schopnosti k práci odbornej sú pridržiavaní $k$ pomocnej práci, najmä v záhrade a na statku, kde dorastajú v budúcich pol'nohospodárskych robotníkov. ${ }^{159}$ Pokial' ide o remeselnú výučbu, ústavné dielne ponúkali možnost' uplatnenia v širokej ponuke remesiel (17 v roku 1928). Chovanci navyše odchádzali z ústavu s výučným alebo tovarišským listom, pričom ústav im na čas po prepustení zabezpečoval pracovné miesto. Komenského ústav bol zriadený na rozlohe asi 17 ha pôdy a mal pavilonovitý ráz. Disponoval rozsiahlym záhradníctvom rôzneho druhu vrátane kvetinárstva, zeleninárstva, škôlkárstva a ovocinárstva s množstvom skleníkov pre zimné pestovanie. Ústav navyše pre svoje potreby užíval hospodárstvo v Opátskom o výmere 220 ha ornej pôdy, lúk a lesa, ktoré predstavovalo jednak zdroj príjmov, ale aj d’alší priestor pre výchovu chovancov $\mathrm{k}$ pol'nohospodárskym činnostiam. ${ }^{60}$

Uvádzame dostupné štatistiky do roku 1928:61

Prijatých chovancov

\begin{tabular}{|l|l|l|l|}
\hline obdobie & odd. justičné & odd. soc. pečlivosti & spolu \\
\hline $1919-1928$ & 842 & 948 & 1790 \\
\hline
\end{tabular}

Prepustených chovancov

\begin{tabular}{|l|l|l|l|}
\hline obdobie & odd. justičné & odd. soc. pečlivosti & spolu \\
\hline $1920-1928$ & 630 & 735 & 1365 \\
\hline
\end{tabular}

Z prepustených chovancov

\begin{tabular}{|l|l|l|l|}
\hline Obdobie & na doučenie remeslu & s výučným listom & s tovarišským listom \\
\hline $1920-1928$ & 272 & 254 & 6 \\
\hline
\end{tabular}

Zo všetkých chovancov na slobode osvedčilo sa:

\begin{tabular}{|l|l|l|l|}
\hline obdobie & osvedčilo sa: & odd. justičné & odd. soc. pečlivosti \\
\hline \multirow{3}{*}{$1920-1928$} & vel'mi dobre & $16 \%$ & $32 \%$ \\
\cline { 2 - 4 } & dobre & $51 \%$ & $45 \%$ \\
\cline { 2 - 4 } & neosvedčilo sa & $22 \%$ & $17 \%$ \\
\cline { 2 - 4 } & neznáme & $11 \%$ & $6 \%$ \\
\hline
\end{tabular}

Z dostupných údajov môžeme dospiet' $\mathrm{k}$ záveru, že úspešnost' polepšovacej výchovy sa $\mathrm{v}$ uvádzanom období v Komenského ústave pohybovala na úrovni približne 70\%.

\section{ZÁVER}

Za ciel' tohto článku sme si v prvom rade stanovili vykonanie analýzy a komparácie inštitútu polepšovacej výchovy ako podl'a pôvodnej uhorskej právnej úpravy, tak aj v rámci unifikujúcich ustanovení zákona č. 48/1931 Sb. o trestnom súdnictve nad mládežou. Zistili sme,

58 KOČÍ, F.: Komenského ústav v Košiciach. In: Mesto Košice 1932. Banská Bystrica: Slovan, 1932 , s. 61.

59 KOČÍ, F.: Komenského ústav v Košiciach. In: Mesto Košice 1932. Banská Bystrica: Slovan, 1932 , s. 63.

60 STUNA, S.: Prehl'ad vývoja a pôsobenie ústavu. In: Komenského ústav v Košiciach 1919 - 1929. Košice: Štátna knihtlačiareň v Košiciach, 1929, s. 22.

61 Údaje sú prevzaté z publikácie: Komenského ústav v Košiciach 1919-1929. Košice: Štátna knihtlačiareň v Košiciach, 1929, s. $26-28$. 
že uvádzaná sankcia v podobe, v akej ju poznal uhorský trestný zákon, zák. čl. V/1878 bola zreformovaná zákonným článkom XXXVI/1908, ktorým došlo ku rozšíreniu podmienok pre jej použitie, ako aj $\mathrm{k}$ zmene jej charakteru $\mathrm{z}$ výnimočného na - v zásade prioritne ukladané opatrenie. Dospeli sme k záveru, že uhorská právna úprava bola zrozumitel'ná, logická a podrobná. Za hlavný prínos československého ZoTSM považujeme najmä odstránenie dualistickej právnej úpravy, ktorá bola $\mathrm{v}$ unitárnom štáte krajne nepriaznivým javom. Pri porovnaní právnej úpravy polepšovacej, resp. ochrannej výchovy v medziach ZoTSM s pôvodnou uhorskou právnou úpravou na území Slovenska však nie sme presvedčení o kvalitatívne vyššej úrovni unifikovanej úpravy. Prvú hypotézu vytýčenú v tejto súvislosti v úvode tohto článku tak považujeme za nepotvrdenú. Ďalším ciel’om tohto článku bol výskum podmienok výkonu polepšovacej, resp. ochrannej výchovy v Košiciach ako aj výskum okolností transformácie ústavu $\mathrm{z}$ uhorskej polepšovne na československú inštitúciu. Výskumom dostupných prameňov sme zistili dva okruhy problémov, ktorým čelilo nové vedenie košického ústavu a to problémy personálne a materiálne. Hypotéza predvídajúca problematickost' preberania štátnej moci v košickom ústave po vzniku Československej republiky bola teda v plnej miere potvrdená. Výskumom sme tiež zistili, že košický ústav sa po prekonaní prvotných t'ažkostí pretvoril na úspešnú inštitúciu disponujúcu potrebným materiálnym vybavením, pričom zabezpečoval okrem školskej výchovy aj výchovu pracovnú, ktorá mohla vyústit' do získania výučného a tovarišského listu a napomôct' tak prepustenému chovancovi $\mathrm{k}$ uplatneniu na trhu práce a $\mathrm{v}$ d’alšom živote. $\mathrm{Na}$ záver konštatujeme, že ešte evidujeme priestor pre d'alší výskum súvisiacich otázok a to najmä vo vzt'ahu k obdobiu po prijatí unifikovanej právnej úpravy do rozpadu medzivojnovej republiky (1931-1938). To otvára priestor pre budúce publikácie v skúmanej oblasti.

\section{KLÚČOVÉ SLOVÁ}

trestné právo, mladiství, Uhorsko, Československo, polepšovacia výchova

\section{KEY WORDS}

criminal law, juveniles, Hungary, Czechoslovakia, reformatory training

\section{POUŽITÁ LITERATÚRA}

1. ANGYAL, P.: Fiatalkorúak és bünteőnovella. Budapešt': Athenaeum, 1912. $160 \mathrm{~s}$.

2. BENCSIK, J.: Egyes rendelkezések ismertetése a fiatalkorúak bíróságáról (1913:VII. t.-c.). In: Bünügyi szemle, roč. 4, 1915, č.3, s. 98-103.

3. BĚLOHLÁVEK, A.: Komenského ústav před 10 lety. In: Komenského ústav v Košiciach 1919-1929. Košice: Štátna knihtlačiareň v Košiciach, 1929, s. 5-11.

4. ČIČ, M.: Ochranná výchova v československom trestnom práve. Bratislava: Obzor, 1971. $128 \mathrm{~s}$.

5. EDVI ILLÉS, K.: Büntetőnovella zsebkönyve. 4. vydanie. Budapest: Révai testvérek irod. intézet b.t. kiadása, 1910. $347 \mathrm{~s}$.

6. FICO, M.: L'udský vek ako okolnost' vylučujúca trestnú zodpovednost' v procese unifikácie československého trestného trestného práva. In: Historia et theoria iuris, roč. 9, 2017, č. 1 2, s. 46-55.

7. FICO, M.: Základy trestnej zodpovednosti $\mathrm{v}$ procese unifikácie trestného práva medzivojnovej Československej republiky. Košice: ŠafárikPress, 2020. 170 s. ISBN 97880-8152-840-8.

8. FENYK, J. - CÍSAŘOVÁ, D.: Meziválečné trestní právo a věda trestního práva $\mathrm{v}$ Československu. In: MALÝ, K. - SOUKUP, L.: Československé právo a právní věda v 
meziválečném období (1918-1938) a jejich místo ve Strědní Evropě, svazek 2. Praha: Karolinum, 2010, s. 821-842.

9. KALlAB, J.: Stručný výklad zákona z 11. března 1931 č. 48 Sb. z. a n. O trestním soudnictví nad mládeží. Brno: Československý akademický spolok Právník, 1931. 39 s.

10. KOČí, F.: Komenského ústav v Košiciach. In: Mesto Košice 1932. Banská Bystrica: Slovan, 1932, s. 59-65.

11. LÖRINCZ, J.: A fiatalkorúak büntetés-végrehajtása a XX. század első felében. In: Börtönügyi szemle, roč. 21, 2002, č. 2, s. 57-66.

12. MIŘIČKA, A. - SCHOLZ, O.: O trestním soudnictví nad mládeží. Praha: Československý kompas, 1932. $309 \mathrm{~s}$.

13. PALGUTA, V.: Fiatalkorúak és a büntetőnovella. In: Jogtörténeti szemle, roč. 30, 2016, č. 1, s. 60-65.

14. STUNA, S.: Prehl'ad vývoja a pôsobenie ústavu. In: Komenského ústav v Košiciach 19191929. Košice: Štátna knihtlačiareň v Košiciach, 1929, s. 18-25.

15. STUNA, S.: Komenského ústav v Košiciach. In: Jubilejný almanach mesta Košíc a Východ. Slovenska 1918-1928. Košice: Slovenská knihtlačiareň v Košiciach, 1928, s. 127-133.

16. VÍTĚZ, J.: První počátky ústavu. In: Komenského ústav v Košiciach 1919-1929. Košice: Štátna knihtlačiareň v Košiciach, 1929, s. 12-13.

\section{PRÁVNE PREDPISY}

1. Zák. čl. V/1878 uhorský trestný zákon o zločinoch a prečinoch.

2. Zák. čl. XXXVI/1908 o doplnení a úprave trestných zákonov a trestného poriadku.

3. Zák. čl. VII/1913 o súdoch mladistvých.

4. Nariadenie uhorského kr. ministra spravodlivosti č. 27.200/1909 I.M. o úprave polepšovacej výchovy.

5. Dôvodová správa Ministerstva spravodlivosti k Zák. čl. XXXVI/1908, Corupus Iuris Hungarici, 1908 évi törvénycikkek. Budapest: Franklin- Társulat, 1909. 1314 s.

6. Nariadenie vlády Československej republiky č. 609 zo 14. novembra 1919.

7. Vládne nariadenie zo dňa 11. decembra 1931 č. 195 Sb. z. a n., ktorým sa vykonáva zákon o trestnom súdnictve nad mládežou.

8. Výnos ministerstva spravodlivosti Československej republiky zo dňa 1. septembra 1931 č. 37.775 , č. 18. Věst, ktorým sa ustanovuje, v ktorých ústavoch a väzniciach sa vykonávajú tresty zavretia.

9. Výnos ministerstva spravodlivosti Československej republiky zo dňa 11. septembra 1931 č. 41209/31 o výkone trestu zavretia.

\section{KONTAKTNÉ ÚDAJE AUTORA}

JUDr. Dávid Pandy

Interný doktorand

Univerzita Pavla Jozefa Šafárika v Košiciach

Právnická fakulta, Katedra dejín štátu a práva

Kováčska 30, 04001 Košice, Slovenská republika

Telefón: +421552344130

E-mail: david.pandy@student.upjs.sk 